\title{
ГОЛОС РОЗМОВНИЙ І ГОЛОС ВОКАЛЬНИЙ. ВІДМІННОСТІ В МЕТОДИКАХ ПОСТАНОВКИ
}

У статті розглянуто проблемні аспекти й зазначено певні відмінності в методиках постановки розмовного та вокального голосу під час підготовки майбутніх акторів драматичного театру та кіно.

Ключові слова: голос, постановка, звук вокальний і розмовний, звукова природа, діапазонна варіативність.

В статье рассмотрены проблемные аспекты и указаны некоторые различия в методиках постановки разговорного и вокального голоса при подготовке будущих актёров драматического театра и кино.

Ключевые слова: голос, постановка, звук вокальный и разговорный, звуковая природа, диапазонная вариативность.

Thearticle deals with the problematic aspects and specifies certain differences in the methods of setting up the spoken and vocal voice during the preparation of future actors of drama theater and cinema.

Key words: voice, statement, sound vocal and spoken, sound nature, rangevariation.

За метою застосовування та за процесом голосоутворення людський голос поділяється на вокальний, розмовний та шепітний. Вокальний голос - це, як відомо, виконання музичного твору за допомогою голосу, передавання художнього змісту музичного твору засобами голосу. Існує три види вокального голосу: академічний, народний, естрадний. Розмовний голос буває професійний і побутовий (у щоденному житті). Внаслідок тертя струменя повітря об стінки гортані, ротової та носової порожнин під час вдиху чи видиху виникає так звана шепітна мова. Це відбувається без участі голосових зв'язок, але їхнє певне зближення наявне.

Професійний голос відрізняється витривалістю щодо мовноголосового навантаження, широтою діапазону, дикційною чіткістю і виразністю, вправним володінням різними темпами мовлення та силою звучання.

3 приводу якості деяких розмовних побутових голосів режисер, актор і педагог М.К. Вороний, зокрема, зауважував, що вони бувають навіть «невдячні, з нечистим звуком - глухі, хрипкі <..> верескливі < ..> Здебільшого сі вади не органічні, а набуті, здавна засвоєні» $[1,76]$.

Для характеристик якості вокального голосу професор Л. Б. Дмитрієв використовує порівняння: «голос, що ллється, або, навпаки, прямий; округлий або плаский; м'який або жорсткий, різкий; блискучий, металевий або матовий; грудний або головний; розсипаний або зібраний, сконцентрований; на опорі чи без опори, далекий чи близький тощо. Розрізняють голоси затиснені, тремтячі, гугняві» $[2,9]$.

Вочевидь за допомогою певних порівнянь щодо властивостей голосу та мовленнєвої поведінки пересічної людини можна провести певні аналогії з рисами іiі характеру, вдачі, статусу. Та й емоційні стани завжди відображаються в людському голосі: радість, гнів, співчуття, подив, роздратованість, пригніченість, приголомшеність тощо.

Як відомо, 38\% інформації доходить до нас саме через голос, тон і тембр (від фр. timbre якість, окраса звуку).

Актор на ігровому майданчику, ведучий телевізійних програм, журналіст на телебаченні чи радіо тримає нашу увагу не лише змістом тексту, а й своєрідністю забарвлення звука — тембром голосу та його енергією. В актора, звісно, енергія звучання голосу безпосередньо залежить від конкретики дії за допомогою слова, що народжується в результаті внутрішнього процесу проживання певних обставин у драматургії ситуації, ролі.

Говорячи про варіативність спектра тембрального забарвлення акторського голосу при роботі над роллю доречно буде згадати слова актора i театрального педагога Л. Ф. Макар'єва: «Голос людини - це його біографія. Він виховується ра- 
зом $з$ людиною. Голос - це звук, і тембр, і глибина, i “гора", i “низ”, і почуття, і думка. Власне кажучи, голос - це “Я”, яким мене створила природа, довкілля і я сам. "Розмовний голос" - це будівельний матеріал, з якого будується сценічна дія. Це - складова частина, але вирішальна у створенні самої “сценічної людини” <... Формування звука - мови персонажа - $є$ завдання роботи над роллю, бік утворення сценічної людини - творче завдання в роботі над образом» $[3$, 61]. I якщо зважати на те, що в театрі ми не лише дивимося виставу, а й слухаємо, то можна розглядати голос актора як «останній етап перед сприйняттям тексту вистави глядачем» $[4,35]$.

Слова «постановка голосу» означають: за допомогою упорядкованого фонаційного дихання опанувати технічними прийомами голосоведіння та резонування, використати і посилити резонансно-енергетичне й розширити діапазонне звучання голосу, покращити його рухливість, мелодійність, витривалість. М.К. Вороний «правильною постановкою голосу» називав таку, «при якій голос має: милозвучність, повноту, силу, витриманість і гнучкість» $[1,75]$.

У драматичному театрі актор має можливість використовувати різні способи виконання пісні. Однак важливим залишається не стільки те, як виконавець «дістає», «ставить» ноту, а те, як він «діє» та «живе» в «запропонованих обставинах». Адже тих, хто слухає, цікавлять не лише вокал, текст пісні, а й підтекст, словесна дія: що ж змушує вимовляти ті чи інші слова, тобто - що $є$ імпульсом для вимови і з яким наміром?

Історія театру та кіно знає достатньо прикладів, коли актори, не маючи від природи особливих вокальних даних, були прекрасними й переконливими виконавцями пісень. Це і М. Водяний, i М. Бернес, В. Висоцький і А. Миронов, Л. Утьосов та багато інших. Дехто із драматичних акторів у музичних виставах, на естраді, в кіно виконували (і виконують) пісні у формі вокального речитативу (ритмічно-наспівне промовляння тексту). Як тут не згадати М. Яковченка, М. Криницину, Н. Копержинську, М. Крамара, М. Гринька, О. Борисова і ще, й ще багатьох. Своєрідність виконання ними пісень у виставах (фільмах) $є$ неймовірно захоплюючою i близькою до природи драматичного театру. Тут уже йдеться не просто про вокальний, а про характерний спів, який цілісно й зримо доповнює певний образ героя, розкриває ще одну грань його вдачі.

У теоретично-практичних засадах дисципліни «Сценічна мова» під час роботи над постанов- кою розмовного голосу досить часто використовується певна інформація про особливості будови голосового апарату та механізму утворення первинного тону голосу, що так ретельно досліджені й описані в посібниках 3 вокальної методики. Під час постановки розмовного голосу застосування цих положень відбувається вибірково, оскільки в роботі над звуком співочим і мовним наявні відмінності. Чимало авторів праць з вокальної методики також зауважують про це.

У контексті методу підготовки акторів драматичного театру основним завданням $€$ збагатити й розвинути розмовний голос. Відповідним чином, це мусить корегувати й сам процес постановки вокального голосу в майбутніх акторів.

Говорячи про різницю між вокальною і розмовною постановками голосу, насамперед слід сказати про те, чим несхожа їхня звукова природа:

- вокальний звук - точність звучання визначена нотами (майже «математична» за В.К. Сережниковим);

- розмовний звук - синусоїдальне коливання висоти і тривалості звука 3 наявністю відтінків під час звучання, що не підлягає точному (нотному) визначенню.

Свого часу М.К. Вороний наголошував на тому, що «співоча постановка голосу обчислена на довгі, тягучі звуки; тому вона позбавляє живого колориту короткі й рухливі звуки звичайної мови, якою говорить драматичний артист. Співочі вправи $<\ldots>$ можуть бути до певної міри корисні i драматичному артистові, але для інших цілей, i в жодному разі ними не радять надуживати» [1, 76-77]. Режисер В.К. Сережников, зокрема, також зазначав, що «у виразному мовленні, особливо в пожвавленому мовленні реалістичного (наближеного до життя, розмовного) характеру, відхилення від висоти розмовного звуку є більшим, ніж у вокальному. Але різкість інтервалів у мові пом'якшується притаманною ій хроматичністю (під'їздами та спусканнями): мовний звук <..> супроводжується іншими звуками, що до нього «притулені». От ці «притулені» звуки (акорди) і збагачують нашу мову обертонами. Чим більше обертонів, тим мова звучить повніше, красивіше» $[5,43]$. У контексті методичної різниці постановки голосів це означає, що «один метод спрямований на те, щоб звук був цілком визначений за висотою, брався відразу й утримувався на даній висоті, а інший — на те, щоб звук утримував лише відносну висоту» $[5,43]$. Адже в мовленнєвому акті ми затримуємося на одній висоті тону лише в якійсь надзвичайній ситуації. 
Для співочих голосів у високій теситурі значущою ділянкою голосу $є$ головний регістр, а «фундаментом» для звучання розмовного голосу - мікстовий середній регістр. У голосі драматичного актора обов'язково потрібно розвивати голосовий діапазон (від гр. diapason - через усі струни), весь об'єм голосу, звукову сукупність від найнижчої до найвищої межі зміни гучності голосу за силою і висотою. Однак передусім слідформувати звучання «природної середини» (за К. С. Станіславським).

Також слід зазначити, що під час розмови і приголосні звучать набагато міцніше, а звучання голосних - без вібрації, як у вокалі. При вимові приголосних видихуваний струмінь повітря призупиняється, активізуючи комплекс м'язів, що задіяні в процесі артикуляції та дихання. Через те й у постановці розмовного голосу, контролюючи точність вимови голосних (зазвичай коротших за звучанням аніж у вокалі), не менш виразний акцент робиться на вимові приголосних звуків. Вокальна ж постановка голосу розрахована на протяжне звучання голосних.

Як уже зазначалося, мовленнєві звуки верхньої частини діапазону слабші, небагаті призвуками. У вокалі групи обертонів високочастотного спектра мають назву високої співочої форманти (від лат. formans (formantis) — той, що формує, створює), яка в мові досягає лише 5-ти - 7-ми відсотків (за Л.Б. Дмитрієвим). Вони створюють специфічний співочий характер звучання голосу й не мають жодного відношення до формант голосних звуків у мовленні (за Л. А. Зарицьким, В.А. Триносом, Л.А.Триносом). До слова, це дуже помітно в розмовному голосі співаків з вокальними голосами високого і найвищого регістру (тенор, сопрано, колоратурне сопрано). В процесі мовлення вони продовжують «перебувати» у вокальній позиції звичної для них теситури (висотне положення голосу). Їхній голос звучить дзвінко, без резонансу в мікстовому чи нижньому регістрі. Адже постійне існування у високому резонаторі стає для артиста «частиною емоційної структури», за словами Сіселі Беррі (Великобританія). Про надлишок верхнього резонансу в мовленні Беррі говорить так: «Концентрація енергії у верхньому резонаторі надає голосу металевого відтінку, а слух артиста звикає до цього звучання. Насправді вухо слухача не сприймає належним чином структуру такого голосу, бо він тонкий i позбавлений теплоти, яку дають низькі звуки, в результаті можливості голосу достатньо обмежені» $[6,6-7]$. Подеколи це впливає на голосову пластику й стає причиною для появи голосових перепадів у розмовному голосі (з різкими переходами у звуковисотному діапазоні).

Про непритаманність розмовній мові найвищих співочих нот, сформованих у головному резонаторі, свого часу писала й театральний педагог К.В.Куракіна: «Ми користуємося ними в буквальному розумінні лише секундами (під час сміху, вигуків). У звичайній мові найвищий розмовний голос не звучить на таких "неймовірно" високих нотах. Це - ділянка вокалу» [7, 87].

Висока голосова тесситура передбачає та вимагає зміни положення гортані: підняття гортані вище, аніж у розмовній позиції.

Під час співу активнішою $є$ внутрішньогортанна артикуляція, а зовнішня - більш пасивна.

У своїй книжці «Техника речи» В.К. Сережников цитує актора та педагога 3 техніки мови В. В. Сладкопєвцева: «Вокальна постановка врешті-решт знебарвлює розмовну мову як 3 боку чистого звукового, так і з боку яскравості почуття. Коротко кажучи, досить часто те, що для співу $\epsilon$ позитивним, для мови буде недоліком і навпаки» $[5,44]$.

Надзвичайно важливим фактором у процесі підготовки акторів драматичного театру є злагодженість у роботі сцен мовника і вокаліста та певна узгодженість щодо методів роботи над голосом. Особливо на початковому етапі навчання. Адже йдеться про один і той самий мовний апарат студента. Репертуар для роботи над співом насамперед має підбиратися, зважаючи на проблеми i завдання в роботі над постановкою розмовного голосу. Суттєвим $є$ й те, що постановка як розмовного, так і вокального голосу неможлива без правильної постановки дихання. Не має ніякої користі спів, коли «виконавець» вокального номеру «дістає» ноту у високій голосовій теситурі, не маючи при цьому опори дихання. Та й спів (знову ж таки у високій голосовій теситурі) завдяки твердій атаці звука, коли голосові зв'язки міцно змикаються перед початком звука й різко роз'єднуються під доволі потужним натиском повітря, (що вже більш схоже не на спів, а на крик) - не сприяє у постановці ні вокального, ні розмовного голосу. Більше того, зазначені хиби $€$ небезпечними для голосових зв'язок виконавця. Надмірне «захоплення» верхніми нотами, спів «не в своїй» теситурі призводить до перевтоми голосового апарату, а через голосове перенавантаження i перенапруження виникають функціональні порушення й розлади голосу.

Часто для прикладу про наявність суттєвої розбіжності в методиках дослідники цього пи- 
тання згадують слова з автобіографії італійського актора Томазо Сальвіні, який доволі успішно навчався співу й навіть виступав у опері з відомими співаками, але згодом дійшов такого висновку: «Невдовзі я збагнув <..> що спів і декламація несумісні, адже методи постановки абсолютно різні в обох випадках і мають шкодити один одному» $[5,44]$. Слово «декламація» неістотно змінює зміст сказаного, і проблема залишається актуальною й сьогодні.

\section{Джерела та література}

1. Вороний М. К. Драма і театр / М. К. Вороний. - К. : Мистецтво, 1989. - $408 \mathrm{c.}$

2. Дмитриев Л. Б. Основы вокальной методики / Л. Б. Дмитриев. - М. : Музыка, 2007. - 368 с. : нот., ил.

3. Ласкавая Е. В. Сценическая речь / Е. В. Ласкавая. - М. : ВЦХТ («Я вхожу в мир искусств»), 2005. -144 с.

4. Дятчук В. В., Барабан Л. І. Український тлумачний словник театральної лексики / В.В.Дятчук, Л.І.Барабан. 2-ге вид., переробл. і допов. - К. : Вид. центр «Просвіта», 2002. — 192 с. :іл.
5. 5. Сережников В.К. Техника речи : пособие для чтецов, певцов, актеров... / Проф. В. К. Сережников. -М. - Театральное изд-во, 1926. $-124 \mathrm{c}$.

6. 6. Берри Сисели. Голос и актер / Сисели Берри. - М. : Московский фонд сохранения культуры, 1996. - 40 с.

7. 7. Куракина К. В. Основы техники речи в трудах К. С. Станиславского / К. В. Куракина. - М., 1959.- 104 с.

\section{References}

1. Voronyi, M. K. Drama i teatr / M. K. Voronyi. - K. : Mystetstvo, 1989. - $408 \mathrm{~s}$.

2. Dmitriev, L. B. Osnovyi vokalnoy metodiki L. B. Dmitriev. - M. : Muzyika, 2007. — 368 s. : not., il.

3. Laskavaya, E. V. Stsenicheskaya rech / E. V. Laskavaya. M. : VTsHT («Ya vhozhu v mir iskusstv»), 2005. -144 s.

4. Diatchuk, V. V., Baraban L. I. Ukrainskyi tlumachnyi slovnyk teatralnoi leksyky / V. V. Diatchuk, L. I. Baraban. - 2-he vyd., pererobl. i dopov. - K. : Vyd. tsentr «Prosvita», 2002. - 192 s. :il.

5. Serezhnikov, V.K. Tehnika rechi : posobie dlya chtetsov, pevtsov, akterov... / Prof. V.K. Serezhnikov. - M. Teatralnoe izd-vo, 1926. $-124 \mathrm{~s}$.

6. 6. Berri, Siseli. Golos i akter/Siseli Berri. - M. : Moskovskiy fond sohraneniya kulturyi, 1996. - 40 s.

7. 7. Kurakina, K. V. Osnovyi tehniki rechi v trudah K. S. Stanislavskogo / K. V. Kurakina. - M., 1959. - 104 s. 